\section{References}

1 Wing AJ, Brunner FP, Brynger $\mathrm{H}$, et al. Combined report on regular dialysis and transplantation in Europe XIII 1982. Proc Eur Dial Transplant Assoc $1983 ; 20: 2-76$

2 Gutman RA, Stead WW, Robinson RR. Physical activity and employmen status of patients on maintenance dialysis. N Engl f Med 1981;304:309-13. Lindner A, Charra B, Sherrard DJ, Scribner BH. Accelerated atherosclerosis in prolonged maintenance hemodialysis. $N$ Engl f Med 1974;290:697-701. riffiths CJ Murray A, Hunter S. Computer assis

analysis. Clin Phys Physiol Meas 1982;3:103-14. and ${ }^{2}$ G Trail TA, Hall RJC, Brown DJ. Echocardiographic features of secondary left ventricular hypertrophy. Br Heart f 1979;41:54-9.

Venco A, Gibson DG, Brown DJ. Relation between the apexcardiogram and changes in left ventricular pressure and dimension. $B r$ Heart $\mathcal{f} 1977 ; 39$

8 Chen W, Gibson DG. Relation of isovolumic relaxation to left ventricular wall movement in man. Br Heart 7 1979;42:51-6.

Armitage P. Statistical methods in medical research. Oxford: Blackwell Scientific,

$10 \mathrm{Kreiss} \mathrm{H}$. Selection of hemodialysis versus cadaveric transplantation. Kidney Int 1978:13 (suppl 8):S91-4.
11 Brynger $\mathrm{H}$, Brunner FP, Chantler $\mathrm{C}$, et al Combined report on regular dialysis and transplantation in Europe $\mathrm{X}$ 1979. Proc Eur Dial Transplant Assoc 1980; and tran

12 Schott CR, Le Sar JF, Kotler MN, Parry WR, Segal BL. The spectrum of echocardiographic findings in chronic renal failure. Cardiovascular Medicine $1978 ; 3: 217-27$

13 D'Cruz IA, Bhatt GR, Cohen HC, Glick G. Echocardiographic detection of cardiac involvement in patients with chronic renal failure. Arch Intern Med $1978 ; 138: 720-4$

14 Drueke T, Le Pailleur C, Sigal-Saglier M, et al. Left ventricular function in haemodialysed patients with cardiomegaly. Nephron 1981;28:80-7

15 Oldershaw PJ, Dawkins KD, Ward DE, Gibson DG. Diastolic mechanisms of mpaired exercise tolerance in aortic valve disease. Br Heart $\mathcal{F} 1983 ; 49: 568-73$ atherosclerosis in long-term dialysis and renal-transplant patients: fact of atherosclerosis in long-term

17 Von Bibra H, Castro L. Autenrieth G, McLeod A, Gurland HJ. The effects of arteriovenous shunts on cardiac function in renal dialysis patients-an echoarteriovenous shunts on cardiac function in renal dialy

18 Haire $\mathrm{H}$, Sherrard D, Scardapane D, et al. Smoking, hypertension and mortality in a maintenance dialysis population. Cardiovascular Medicine 1978;3:1163.

\title{
Primary biliary cirrhosis, dark adaptometry, electro-oculography, and vitamin A state
}

\author{
A N SHEPHERD, G J BEDFORD, A HILL, I A D BOUCHIER
}

\begin{abstract}
Twenty five patients with primary biliary cirrhosis were studied for vitamin A state. In nine patients found to have low circulating vitamin $A$ concentrations no abnormality was found on electro-oculography or in dark adaptation. A positive correlation was found between retinol binding protein and vitamin $A$ values $(\mathbf{r}=+0.88 ; \mathbf{p}<0.001)$ and between serum albumin and vitamin $A$ values $(r=+0.75 ; p<0.001)$. A weaker and negative correlation was found between serum bilirubin $(r=-0.47 ; p<0.05)$ and vitamin $A$ values.

Patients with primary biliary cirrhosis should not receive regular parenteral or even oral vitamin $A$ supplementation unless dark adaptometry or electrooculography yields an abnormal result.
\end{abstract}

\section{Introduction}

The relation between vitamin A deficiency and skin and ocular abnormalities, including keratomalacia and night blindness, has been known for years. The association of primary biliary cirrhosis with vitamin A deficiency is well documented. ${ }^{1}$ Patients with primary biliary cirrhosis have a reputedly high incidence of vitamin A deficiency, which has resulted in the widespread use of both parenteral and oral vitamin A supplementation to reduce the risk of ocular complications. ${ }^{2-4}$ We find that clinical vitamin A deficiency is a rare occurrence. We therefore studied the vitamin A state in our patients with primary biliary cirrhosis in an attempt to rationalise the use of vitamin A supplementation.

\footnotetext{
University Departments of Medicine and Ophthalmology, Ninewells Hospital and Medical School, Dundee DD1 9SY

A N SHEPHERD, BSC, MRCP, lecturer in medicine

G J BEDFORD, BSC, FRCS, senior registrar in ophthalmology

A HILL, LRIC, MIBIOL, chief technician, university department of medicine

I A D BOUCHIER, MD, FRCP, professor of medicine

Correspondence to: Dr A N Shepherd.
}

\section{Patients and methods}

Twenty five patients with primary biliary cirrhosis (biopsy proved, and positive antimitochondrial antibodies to a titre of $>1 / 64$ ) were selected. Fourteen were Childe's grade A, three Childe's grade $B$, and eight Childe's grade C. None of the patients were receiving fat restriction or vitamin A supplementation. All underwent full biochemical and haematological screening as part of the study. Concentrations of vitamin A (standard flurometric method; normal range $1-3 \mu \mathrm{mol} / 1(28 \cdot 7-86 \cdot 0 \mu \mathrm{g} / 100 \mathrm{ml}))^{5}$ and retinol binding proteins (immunodiffusion method, L C Partigan, Behring; normal range 3-5 $\mathrm{mg} / \mathrm{dl}$ ) were measured in all patients. Nine patients who were found to have low vitamin A concentrations were further studied independently by standard dark adaptometry (using a Freidmann analyser) and electro-oculography (using a Medelec electrical potential averager). The study was approved by the local ethical committee.

\section{Results}

At the time of the study no patient had any clinical features of vitamin A deficiency. Alkaline phosphatase and $\gamma$-glutamyltransferase activities were raised in all patients. Vitamin A concentrations were reduced in nine patients (range $0.4-1.3 \mu \mathrm{mol} / 1 ; 11.5-37.2 \mu \mathrm{g} / 100 \mathrm{ml}$ ). Concentrations of retinol binding proteins were reduced in six of nine patients (range $1.5-2.8 \mathrm{mg} / \mathrm{dl}$ ) with low vitamin $A$ but in none of the patients with normal vitamin A values. Three patients with low vitamin $\mathrm{A}$ values had a normal retinol binding protein concentration. Serum albumin values were reduced in eight of the nine patients with low circulating vitamin $\mathrm{A}$ concentrations and in none with normal vitamin A values. Eight patients with low vitamin A concentrations and four with normal values had raised bilirubin concentrations. One patient had a low vitamin $A$ value and a normal bilirubin concentration. There was a strong positive correlation between vitamin $\mathbf{A}$ and retinol binding protein concentrations $(r=+0.88 ; p<0.001)$ and between vitamin $\mathrm{A}$ and serum albumin concentrations $(\mathrm{r}=+0 \cdot 75$ $\mathrm{p}<0.001$ ) (figure) and a weaker, negative correlation between vitamin $\mathrm{A}$ and bilirubin concentrations $(\mathrm{r}=-0.47 ; \mathrm{p}<0.05)$. Dark adaptation and results of electro-oculography were well within our normal range in all nine patients with low vitamin A concentrations who were studied.

\section{Discussion}

There is increasing evidence that vitamin A supplementation in normal subjects may cause hepatotoxicity leading to cirrhosis, 
portal hypertension, and ascites even in dosages as low as 40000 units daily. Several hepatologists recommend high doses of vitamin A and in some cases zinc supplementation to prevent the ocular complications of primary biliary cirrhosis, suggesting up to 25000 units daily. ${ }^{4}$ Possibly those doses recommended might enhance hepatic damage in primary biliary cirrhosis.

By contrast with other studies, we could find no ocular abnormalities in any of our patients despite low circulating vitamin A concentrations, other studies finding as many as

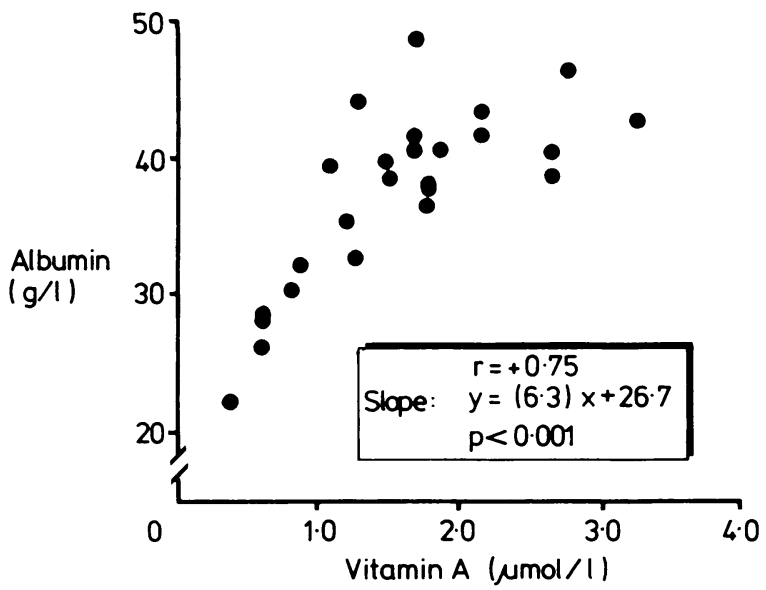

Correlation of vitamin A versus serum albumin concentrations Conversion: SI to traditional units-Vitamin A: $1 \mu \mathrm{mol} / 1 \approx$ $28 \cdot 7 \mu \mathrm{g} / 100 \mathrm{ml}$ nine out of 11 patients with primary biliary cirrhosis and clinical vitamin A deficiency. ${ }^{2}$ Vitamin $\mathrm{A}$ is transported to various tissues as a 1:1 molar complex with retinol binding proteins; as the concentration of these proteins falls so does the apparent value of vitamin A. In this study a serum albumin concentration of $<35 \mathrm{~g} / \mathrm{l}$ suggested the presence of a low circulating vitamin A concentration. Retinol binding protein and albumin production rely heavily on the synthetic capacity of the liver, which is disturbed in primary biliary cirrhosis. Hence despite low recordable vitamin A values the tissue concentrations may be normal. In addition, the rare use of cholestyramine and a normal dietary fat intake in our patients allowed a normal dietary vitamin A intake.

Our data suggest that regular vitamin A supplementation is unnecessary for all patients with primary biliary cirrhosis. A serum albumin concentration of $<35 \mathrm{~g} / 1$ is a level below which yearly ocular evaluation should be considered to assess the need for vitamin A supplementation.

\section{References}

1 Russell R, Morrison S, Smith F, Oaks E, Carney E. Vitamin A reversal of abnormal dark adaptation in cirrhosis. Ann Intern Med 1978;88:622-6.

Herlong $\mathrm{H}$, Russell R, Maddrey W. Vitamin A and zinc therapy in primary biliary cirrhosis. Hepatology $1981 ; 1: 348-51$

3 Sherlock S. Primary biliary cirrhosis: critical evaluation and treatment policies. Scand 7 Gastroenterol 1982 ,suppl $77: 63-74$.

Pitamin A treatment for night blindness in primary biliary cirrhosis. Br Med f 1984;288:1030-1.

5 Stewart WK, Fleming LW. Plasma retinol and retinol binding protein concentration in patients on maintenance haemodialysis with and without vitamin supplements. Nephron 1982;30:15-21.

(Accepted 12 September 1984)

\title{
Factors affecting development of peritonitis in continuous ambulatory peritoneal dialysis
}

\author{
T H J GOODSHIP, A HEATON, R S C RODGER, M K WARD, R WILKINSON， D N S KERR
}

\begin{abstract}
A questionnaire based survey in patients receiving continuous ambulatory peritoneal dialysis showed that there was an increased incidence of upper respiratory tract symptoms (suggestive of viral illness) in the 14 days before the development of peritonitis. No other factors were identified that might distinguish patients who develop peritonitis.

The possibility that viral infections predispose to peritonitis by altering host defence mechanisms in patients receiving this form of renal replacement therapy warrants further study.
\end{abstract}

\section{Introduction}

Continuous ambulatory peritoneal dialysis is now a well established method of renal replacement therapy. Since its introduction in $1978^{1}$ the major complication has remained that of peritonitis. Although in most renal units using the treatment there has been a fall in the incidence of peritonitis, it is still the main source of morbidity. ${ }^{2}$ Most infections are caused by skin commensals, and it is suspected that most episodes are secondary to a breakdown in technique.

In an attempt to elucidate some of the factors that may be important in the development of peritonitis we have carried out a survey on the methods of the exchange technique used by our patients and their association with the development of peritonitis.

\section{Patients and methods}

At the beginning of December 1982 all 97 patients who were being treated by continuous ambulatory peritoneal dialysis and were free of peritonitis were sent a questionnaire. Replies from 94 patients were received. All patients who subsequently joined the treatment programme over the next five months were also given the questionnaire. The questionnaire consisted of two parts (see Appendix). Questions in the first part asked about general hygiene and methods used in the exchange technique, and the second part asked about problems that had occurred in the previous two weeks. 